\title{
HISTORICAL DISSERTATIONS DEFENDED IN 2003
}

Darius Antanavičius (Lithuanian Institute of History, Vytautas Magnus University). Lietuvio bajoro „Dešimtmetis Livonijos karas“ (1610 m.) ir jo autorius (autorystès atribucijos bandymas) [Equitis Lituani de Bello Livonico per Decennium Gesto and its Author. An attempt at attribution].

The subject of this work is an anonymous book, Equitis Lituani de Bello Livonico per Decennium Gesto, which appeared in Vilnius in 1610. This is the only printed text of that time which sets forth in sequence the history of the military actions of the Commonwealth and Sweden in Livonia during 1601-1609. The aim of this study is to ascertain the history of this publication and its place in bibliography and scholarly literature; establish the book's value in Quellenkritik; verify the statement widespread in bibliography that it was written by K. Volodkevičius; and, if no authorship is confirmed, to present another possible author.

The author pursues his aims by combining book-science and historical methods. This gave him an opportunity to refute the accepted view concerning the authorship of this book and establish that Teodoras Lackis, who not only knew several foreign languages and had sufficient education but also took part in the Livonian War, could be considered the author.

Darius Vilimas (Lithuanian Institute of History, Vytautas Magnus University) Lietuvos Didžiosios Kunigaikštystès žemès teismo sistemos formavimasis (1564-1588 m.). [The Formation of the System of Land Courts in the Grand Duchy of Lithuania (1564-1588)].

This study explores the history of the institution of land courts. The author seeks to examine the creation of new land-court structures (in accordance with the provisions of the Second Lithuanian Statute) in the districts (powiat); establish the beginning of the land courts; create a list of the officials of the first land courts during the period between the second and third Lithuanian Statutes (about 160 of all such people were established); and make a prosopographical analysis of the list in order to establish the preconditions for the emergence of groups of district 'lawyers' and the perspective for the further development of this group of the nobility, evaluating these as factors for the development of the legal culture in the GDL in the second half of the sixteenth century. 
After investigating these questions the author stressed that although during 1564-1588 a qualitatively new type of court was created and began to operate in the GDL, the appointment of district land court officials retained many connections with the pre-reform period.

The work is supplemented by the following appendices: lists of surviving GDL land court books from the end of the sixteenth century; the general text of the new GDL administrative divisional document of 1565-1566; and a list of charters delimited by the districts of the GDL.

Audrius Abromaitis (University of Vilnius). Lenkija ir Lietuvos visuomené: požiūriai i Lenkija Lietuvoje 1918-1940 m. [Poland and Lithuanian Society: Attitudes towards Poland in Lithuania 1918-1940].

For the subject of his dissertation the author chose a little studied topic: the attitude of Lithuanian society towards Poland during the interwar period.

The author states in his conclusions that with the rebirth of the Lithuanian nation distinctive political aspirations began to clash with the objectives of Polish political figures. The issue of land played an important role in establishing hostile attitudes towards Poland. No less important was the perception of the threat posed by Polish national identity to its Lithuanian counterpart. But the 1920 s became the apogee of antiPolish attitudes in Lithuania when Lithuanians, seeing no way to recover Vilnius, began to view Poland not only as an enemy of the state but also of the nation. This perception united the greater part of society and the Lithuanian political parties and became a significant factor influencing foreign policy. The turning point occurred with the heating up of Lithuania's conflict with Germany when not only were the priorities of Lithuanian foreign policy rethought but also the Lithuanian assessment of Poland began to change.

Laurynas Jonušauskas (University of Vilnius) Lietuvos diplomatinès tarnybos veikla egzilyje 1940-1991 m. [The Activity of the Lithuanian Diplomatic Service in Exile 1940-1991].

This study investigates the period from the last independent Lithuanian presidential order of Foreign Minister J. Urbšys of 1 June 1940 to Lithuanian ambassadors working in the West, which instructed in case of a state catastrophe to consider the Ambassador to Italy Stasys Lozoraitis to be the head of Lithuanian diplomacy, until 6 September 1991 when the head of Lithuanian diplomacy in exile, S.A. Baškis, handed over his authorisations to the then Lithuanian foreign minister, A. Saudargas. 
The dissertation investigates the relations of the Supreme Lithuanian Liberation Committee founded in 1944 and the representatives of the diplomatic corps; analyses issues decided at various times by the Lithuanian Diplomatic Service: the regular raising of the question of Lithuania in international organisations, the appointment of new Service members and its financing problems, and the view of the restored independent Lithuanian state.

Bernaras Ivanovas (Vytautas Magnus University, Lithuanian Institute of History). Tautiniu mažumu ivvaizdžiai Lietuvoje XX a. 4-tame dešimtmetyje: tautininku ideologinès-politinès srovès pažiūros [The Images of Ethnic Minorities in Lithuania during the 1930s: the Attitude of the Nationalist Party (Tautininkai)].

The author of this work focuses on the Jewish, Polish, and German ethnic minorities. Their integration and the assurance of their loyalty was an important task of Lithuanian society and the state. The Nationalist government purposefully shaped the images of the ethnic minorities. It states that the image of the Jews was the most differentiated, the Zionists and Orthodox Jews being considered the most loyal. The communists and leftist liberal Jews received the most criticism; their support in the cases of the Klaipëda and Vilnius problems was received positively but Jewish desires to participate in municipal institutions were viewed negatively.

The images of the German and Polish minorities were more influenced by political factors. In the case of the Poles, the most important role fell to the problem of the return of Vilnius and discrimination against Lithuanians in the Vilnius region. The attitude towards the Germans was determined by their objectives to re-annex the Klaipèda region and Hitler's coming to power.

The author notes that ethnic images influenced the formation of the Lithuanian national consciousness but played no visible role in seeking to ensure the loyalty of the minorities.

Aušrelè Kristina Pažèraitė (Vytautas Magnus University, Lithuanian Institute of History). Izraelis Salanteris ir Musar judejimas Lietuvoje $X I X a$. [Israel Salanter and the Musar Movement in Lithuania in the Nineteenth Century]

This dissertation seeks to ascertain the significance of the Musar movement on the formation of Litvak Orthodox Judaism. Musar, a traditional rabbinical term, meant that the study of the Talmud should be accompanied by the study of ethics, and suitable conduct. But in the terminology 
of the founder of this movement, Israel Salanter, it included behaviour not only complying with the provisions of Halakh but also foreseeing the social-ethical consequences of such behaviour. In this way the humanistic spirit of the Age of Enlightenment penetrated into the conception of Musar and turned Musar into an educational project: it became a tool for an individual to change his internal attitudes so that a person inertly following the traditions would become a real Jew.

The author investigates the Musar movement while Salanter was still living in Lithuania (the periods in Vilnius (1840-1848) and Kaunas (1849-1857) being distinguished); the spread of the Musar ideas, when his followers began to spread them after Salanter moved to Germany, and the rabbinical studies founded on the basis of Musar; and the genesis and meaning of Musar as a pedagogical tool manifesting itself as purposeful education.

Jonas Vaičenonis (Vytautas Magnus University, Lithuanian Institute of History). Kariuomenès vaidmuo politiniame I Lietuvos Respublikos gyvenime 1927-1940 m. [The Role of the Army in the Political Life of the First Republic of Lithuania (1927-1940)].

The dissertation, in discussing the army's leadership, structure, location, and quantitative and qualitative characteristics, surveys the process of the army's politicization and political activity. The army is investigated as the most important buttress of the authoritarian regime of Antanas Smetona. An analysis of the military situation and of the activities of the military commandant's office, courts-martial, and military censors is presented. The special features of the morality of officers are revealed, the process of the army's relations with the public is analysed, and the role of officers in state political events during 1938-1940 is evaluated.

In conclusion the author stresses that the authoritarian regime, which operated from December 1926 until June 1940, transformed the army into an obedient loyal tool for supporting the policies and disciplined order of the Nationalist Party. Although during 1938-1940 the greater part of officers began to express themselves more actively in the public life of the state, they had no real influence on the political decisions that were taken. 